\title{
BAHASA DAN HABITUS KELAS DALAM BUKU AL-ARABIYAH BAYNA YADAIK JILID 2
}

\author{
Hanifah Nida'uljanah \\ Universitas Sebelas Maret Surakarta \\ hanifah.nidauljanah@gmail \\ Muhammad Ridwan \\ Universitas Sebelas Maret Surakarta \\ muhammadridwan_fib@staff.uns.ac.id
}

\begin{abstract}
This study discusses the habitus of the dominant class in the discourse of the Al-Arabiyah bayna Yadaik volumes 2 book and the habitus-dominated class inside. The main data required for this research are linguistic data, taking form sentences in the discourse used in the book. Data were collected with observation and note-taking methodusing tapping technique to the book of Al-Arabiyah bayna Yadaik vol 2. Tapping technique wascarried out by freely tapping the conversation, in which the researchers watched carefully without participating in the use of language in the book of Al-Arabiyah bayna Yadaik vol 2. Critical discourse analysis approach was applied to find out the sentences in the book discourse indicating and signalizing a certain class habitus. The results of the study reveal that more socialization activities of habitus are conducted in upper class than in lower class. Many sentences indicate thatthe actors of the story are from the upper class. The habitus of upper class is obvious in various mechanisms of socialization such as customs, symbolism and character of the upper class, while the habitus of lower class is only revealed in the imaging profile.
\end{abstract}

Keyword: Discourse, Social class, Critical discourse analysis approach

\begin{abstract}
ABSTRAK
Penelitian ini membahas habitus kelas dominan dalam wacana buku Al-Arabiyah Bayna Yadaik jilid 2 dan habitus kelas terdominasi di dalamnya. Data utama yang diperlukan untuk penelitian ini adalah data kebahasaan berupa kalimat dalam wacana yang digunakan dalam buku tersebut. Data tersebut dikumpulkan dengan metode simak teknik sadap terhadap buku Al-Arabiyah Bayna Yadaik jilid 2. Teknik sadap dilakukan dengan cara sadap bebas libat cakap, yaitu peneliti memerhatikan dengan cermat tanpa ikut berpartisipasi dalam penggunaan bahasa dalam buku Al-Arabiyah Bayna Yadaik jilid 2. Penelitian dilakukan pendekatan analisis wacana kritis yang dilakukan dengan menemukan kalimat dari wacana buku tersebut yang menunjukkan dan mengisyaratkan suatu habitus kelas sosial tertentu.Hasil penelitian yaitu sosialisasi habitus kelas atas lebih banyak dilakukan dalam buku Al-Arabiyah Bayna Yadaik jilid 2 daripada habitus kelas bawah. Banyak kalimat ditemukan dalam bacaan yang mengindikasikan bahwa pelaku cerita berasal dari kelas atas. Habitus kelas atas ditunjukkan dengan berbagai mekanisme sosialisasi,
\end{abstract}


berupa kebiasaan, simbolisasi maupun karakter kelas atas, sedangkan habitus kelas bawah hanya ditampakkan dalam pencitraan profil saja.

Kata kunci: wacana, kelas sosial, analisis wacana kritis

\section{PENGANTAR}

Bahasa merupakan praktik sosial. Melalui bahasa, suatu kelompok sosial saling berinteraksi. Konsekuensi dari pengertian tersebut adalah bahasa dipahami sebagai suatu tindak yang bertujuan. Dengan menggunakan bahasa, seseorang melakukan kegiatan membujuk, mempengaruhi, mendebat, menyanggah, mempertahankan, dan mereaksi orang lain. Selain itu, bahasa juga dipahami sebagai sesuatu yang diekspresikan secara sadar, terkontrol, bukan sesuatu yang di luar kendali atau diekspresikan di luar kesadaran.

Bahasa merupakan salah satu alat yang digunakan kelas dominan untuk menjalankan mekanisme kekerasan simbolik. Bahasa memiliki peran yang sentral dalam mekanisme kekuasaan dan dominasi, terutama untuk menyembunyikan maksud yang sebenarnya dari sebuah tindakan, yang dilatarbelakangi karena adanya unsur kekuasaan. Setiap bahasa (teks, tulisan, dan kalimat) hampir selalu diikuti dengan tujuan yang bersifat laten. Tentu saja, hal ini merupakan proyek besar kelas dominan untuk menyebarluaskan dan memaksakan habitusnya kepada kelas yang didominasi, yaitu kelas bawah.

Bahasa merupakan produk budaya, yang tentu saja tidak dapat dipisahkan dari konteks sosialnya. Bahasa mencerminkan pesan, dalam bahasa Bourdieu, pesan ini dimaknai sebagai simbol. Kelas dominan, melalui bahsa, seolah-olah ingin memberitahukan kepada kelas terdominasi "inilah seleraku", "inilah habitusku", dan "inilah budayaku". Sementara itu, kelas terdominasi tidak memiliki akses yang cukup untuk menyuarakan atau menyosialisasikan habitusnya. Apabila, pandangan ini dikaitkan dengan teori pascakolonial, cukup jelas bahwa kelompok kelas bawah memang tidak memiliki akses yang cukup. Mereka adalah "subaltern" yang tidak mampu bersuara (Martono, 2012:47).

Bahasa, di sisi lain, tentu saja menjadi cermin status sosial. Seseorang dapat menunjukan status sosialnya melalui bahasa yang digunakannya, termasuk di dalamnya adalah pilihan katanya dan cara pengucapannya. Bahasa mencerminkan budaya, gaya hidup, kebiasaan, kepemilikan, dan berjuta simbol kelas lain. Atas dasar itulah, tulisan ini menguraikan mengenai penggunaan bahasa sebagai mekanisme kekerasan simbolik melalui tulisan-tulisan yang dimunculkan dalam buku Al-Arabiyah Bayna Yadaik jilid 2 yang menjadi objek penelitian ini.

Sebagai suatu bentuk praktik sosial, bahasa mengandung pertarungan kepentingan atau pertandingan ideologis. Dengan begitu, fakta sosial yang disampaikan dengan bahasa merupakanhasildariprosespertarungan antara kekuasaan ekonomi, politik, dan sosial yang ada di masyarakat. 
Caranya adalah dengan menggunakan pilihan kata dan tata bahasa tertentu sehingga mengimplikasikan ideologi tertentu. Paparan tersebut memberikan konsekuensi pemahaman bahwa wacana tidak sekadar dipahami sebagai rangkaian kata atau proposisi dalam teks, tetapi sebagai sesuatu yang memproduksi yang lain (sebuah gagasan, konsep, atau efek). Dalam proses memproduksi gagasan tersebut, penutur dipengaruhi oleh konteks sosial budaya tertentu yang berpengaruh terhadap cara berpikir dan bertindak.

Karena adanya perbedaan cara berpikirdan bertindak, setiap proses interaksi selalu ada pihak yang dikuasai dan ada yang menguasai. Kekuasaan berlangsung di manamana. Sebagaimana dikatakan Foucault (Eriyanto, 2001:65-66) bahwa strategi kuasa berlangsung di mana-mana. Di mana saja, ada susunan, aturan-aturan, sistem-sistem regulasi, di mana saja ada manusia yang mempunyai hubungan tertentu, di situ kuasa sedang bekerja. Kuasa tidak datang dari luar tetapi menentukan susunan, aturan-aturan, dan hubungan-hubungan itu dari dalam. Banyak faktor yang menyebabkan seseorang menjadi penguasa dan dikuasai. Di antaranya adalah pengetahuan,ekonomi, politik, dan sosial. Salah satu bentuk pertarungan kekuasaan dapat dilihat dalam arena pendidikan yang disampaikan dalam buku pembelajaran Al-Arabiyah Bayna Yadaik jilid 2.

Pendidikan menurut Bourdieu hanyalah sebuah alat untuk mempertahankan eksistensi kelas dominan. Sekolah pada dasarnya hanya menjalankan proses reproduksi budaya untuk mengabadikan ketidaksetaraan ekonomi antargenerasi (Giddens dalam Martono, 2012:41). Kelas dominan mempertahankan posisinya melalui kurikulum tersembunyi. Sekolah memengaruhi siswa dan kebiasaan siswa dengan menggunakan budaya kelas dominan. Kelas dominan memaksakan kelas terdominasi untuk bersikap dan mengikuti budaya kelas dominan melalui sekolah. Sekolah hampir selalu menerapkan budaya kelas dominan dalam setiap aktivitasnya. Siswa dari latar belakang kelas bawah mengembangkan cara berbicara dan bertindak yang biasa digunakan kelas dominan. Siswa yang memiliki kebiasaan atau habitus yang sesuai dengan kelas dominan akan menerima keberhasilan. Sementara itu, siswa yang tidak mampu menyesuaikan habitusnya akan mengalami kegagalan. Agar kelas bawah dapat berhasil, dia harus meniru habitus kelas dominan. Habitus kelas dominan selalu diposisikan sabagai habitus yang paling baik dan paling sempurna.

\section{TEORI DAN METODE PENELITIAN}

Penelitian ini menjadikan buku AlArabiyah Bayna Yadaik jilid 2 sebagai objek penelitian. Hal ini dilakukan karena buku ini merupakan buku pedoman belajar bahasa Arab bagi seorang pemula yang asli dicetak di Saudi Arabia. Buku ini tidak asing ditelinga para pelajar mahasiswa karena buku ini memang disusun khusus untuk mahasiswa yang ingin belajar bahasa Arab. Buku Al-Arabiyah Bayna Yadaik jilid 2 merupakan buku 
yang mudah dipahami dengan bahasa Arab baku yang menggunakan kosa kata yang sederhana bagi seorang pemula. Oleh sebab itu, penelitian ini dilakukan terhadap buku Al-Arabiyah Bayna Yadaik jilid 2 agar mudah diterima oleh pembaca. Berdasarkan alasan di atas, pembahasan ini difokuskan pada (1) bagaimana penggunaan habitus kelas dominan dalam buku Al-Arabiyah Bayna Yadaik jilid 2? (2) bagaimana habitus kelas terdominasi yang terdapat dalam buku tersebut?

Penelitian yang terkait dengan habitus kelas sosial sudah pernah diteliti sebelumnya, seperti penelitian yang pernah dilakukan oleh Lilik Wahyuni (2008). Penelitiannya berjudul "Kekuasaan Simbolik dalam Wacana Politik di Media Cetak". Penelitian Lilik Wahyuni dapat disimpulkan bahwa pertarungan simbolik dalam wacana politik di media cetak berupa praktik pelestarian doxa oleh kelompok orthodoxa dan penyerangan doxa oleh kelompok heterodoxa. Strategi penyerangan doxa dilakukan dengan (a) menunjukkan kekurangan kelompok orthodoxa, (b) memancing permusuhan dalam tubuh kelompok orthodoxa, (c)penyamaan kelompok orthodoxa dengan kelompok lain, dan (d) menggunakan isu-isu SARA (Suku, Ras, dan Agama) dan golongan. Mekanisme kekerasan simbolik dalam wacana tersebut dilakukan oleh orthodoxa dengan eufimisasi dan sensorisasi.

Penelitian selanjutnya adalah penelitian yang dilakukan oleh Edhi Susilo (2012). Edhi Susilo melakukan penelitian yang berjudul "Orkes Simfoni Jakarta dalam Perspektif Habitus
Bourdieu". Penelitiannya membahas habitus orkes simfoni dan pelaku orkes simfoni menurut perspektif habitus Bourdieu. Orkes simfoni sebagai habitus sudah berlangsung di Indonesia. Perjalanannya diwarnai dengan perubahan-perubahan pada kondisi dan pelakunya. Penelitiannya bertujuan untuk mengetahui sejarah dan perkembangan orkes simfoni di Indonesia.

Penelitian ini berbeda dengan kedua penelitian tersebut. Penelitian ini fokus pada habitus kelas sosial yang ditunjukkan dalam penggunaan bahasa dalam arena pendidikan. Penelitian ini menggunakan objek yaitu buku AlArabiyah Bayna Yadaik jilid 2. Buku ini merupakan buku yang dicetak langsung dari Mesir dan sering digunakan dalam pendampingan belajar bahasa Arab bagi pemula.

Pendekatan yang digunakan dalam penelitian ini yaitu analisis wacana kritis. Analisis wacana kritis merupakan pendekatan yang memandang wacana sebagai praktik sosial. Wacana dikaji dalam dialektika antara bahasa dan struktur sosial. Analisis wacana kritis digunakan untuk menjelaskan tentang cara struktur sosial dibentuk dalam interaksi linguistik kelompok atas. Hal ini berarti wacana menunjukkan suatu kebiasaan/habitus kelompok tertentu dengan situasi yang membentuknya. Kelompok dominan menguasai wacana dan sebaliknya kelompok terdominasi harus mengikuti kebiasaan-kebiasaan yang terdapat dalam wacana tersebut.

Metode dan teknik penelitian yang digunakan dalam penelitian ini mencakup tiga hal, yaitu metode dan 
teknik pengumpulan data, metode dan teknik analisis data, serta metode dan teknik penyajian data. Data utama yang diperlukan dalam penelitian ini adalah kalimat dalam bacaan buku Al-Arabiyah Bayna Yadaik jilid 2 yang menunjukkan, mengandung, dan mengisyaratkan makna habitus kelas sosial tertentu. Habitus diwujudkan dalam kebiasaan, gaya hidup, dan simbol-simbol kepemilikan. Unsur lain yang secara eksplisit maupun implisit mampu mencerminkan simbol-simbol kelas tertentu. Kalimat dikumpulkan dengan menggunakan metode simak teknik sadap terhadap buku Bayna Yadaik jilid 2. Metode simak dilakukan dengan menyimak, yaitu menyimak penggunaan bahasa. Sudaryanto (2015:203) menyatakan bahwa teknik dasar dalam metode simak yaitu teknik sadap. Penyediaan dengan teknik ini dilakukan dengan segenap kecerdikan dan kemauannya dalam menyadap penggunaan bahasa dalam buku Al-ArabiyahBayna Yadaik jilid 2. Kegiatan sadap dilakukan tanpa adanya partisipasi peneliti ketika menyimak. Kegiatan hanya dilakukan dengan memerhatikan penggunaan bahasa tersebut. Teknik ini disebut dengan teknik simak bebas libat cakap (SBLC).

Setelah data terkumpul, tahap selanjutnya yaitu analisis. Penganalisan data mengenai habitus kelas dalam buku Al-Arabiyah Bayna Yadaik jilid 2 menggunakan metode padan, yaitu yang alat penentunya di luar, terlepas, dan tidak menjadi bagian dari bahasa yang bersangkutan. Adapun teknik dasar yang digunakan dalam penelitian ini adalah teknik pilihan unsur penentu
(PUP).Adapun teknikselanjutnya adalah teknik hubung banding menyamakan, hubung banding membedakan, dan hubung banding menyamakan hal pokok. Alat penentu dalam penelitian ini adalah kalimat dalam buku Al-Arabiyah Bayna Yadaik jilid 2 yang menunjukkan habitus kelas sosial tertentu.

Adapun teori yang yang menjadi rujukan penelitian ini adalah teori habitus Pierre Bourdieu. Habitus merupakan gaya hidup, nilai-nilai, watak, dan harapan kelompok sosial (kelas) tertentu. Jadi, setiap kelas akan memiliki habitus yang berbedabeda. Habitus ini digunakan oleh kelas dominan untuk memaksakannya kepada kelas terdominan melalui mekanisme kekuasaan, dalam hal ini yaitu terdapat dalam arena pendidikan.

Untuk menyajikan data yang telah dikumpulkan dan dianalisis sebelumnya, peneliti menampilkannya dalam bentuk laporan tertulis mengenai hasil kerja analisisnya. Metode penyajian data yang digunakan dalam penelitian ini adalah metode informal, yaitu penyajian analisis yang menggunakan kata-kata biasa walaupun dengan terminologi yang sifatnya teknis (Sudaryanto, 2015:241).

\section{HASIL DAN PEMBAHASAN Habitus Kelas Atas}
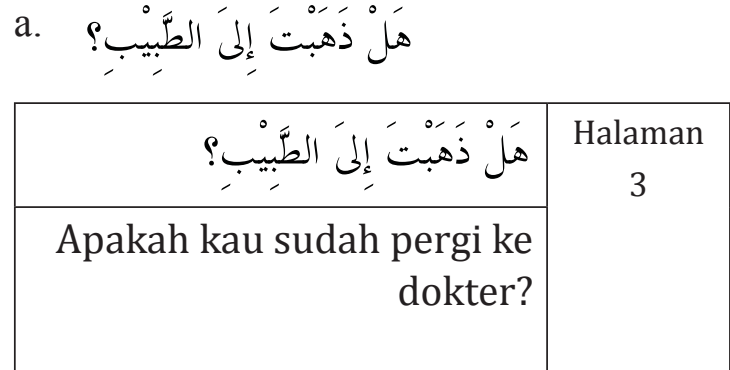
Bentuk sosialisasi habitus kelas atas dalam buku Al-Arabiyah Bayna Yadaik jilid 2 pertama ditampilkan yaitu kebiasaan berobat ke dokter. Kebiasaan ini digunakan untuk mengilustrasikan tindakan yang dilakukan oleh kelas atas ketika jatuh sakit. Kebiasaan ini bukan berarti tidak boleh dilakukan oleh kelas bawah melainkan kebiasaan ini merupakan tindakan yang sering dilakukan oleh kelas atas. Ketika kelas bawah sedang sakit, biasanya cukup dengan meminum obat dan istirahat karena berobat ke dokter memerlukan biaya yang cukup banyak. Kebiasaan ini dikategorikan sebagai habitus kelas atas.

\begin{tabular}{|c|c|}
\hline 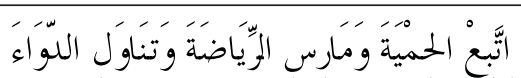 & Halaman \\
\hline $\begin{array}{l}\text { Taatilah pantangan, biasakan } \\
\text { berolahraga, makanlah obat, } \\
\text { dan temui saya sebulan lagi! }\end{array}$ & \\
\hline
\end{tabular}

Kelas atas merasakan
kemantapan jawaban mengenai sakitnya setelah ia pergi ke dokter atau rumah sakit untuk periksa karena inilah habitus kelas atas. Semua yang dikatakan oleh dokter akan dilaksanakan dan semua larangan dokterpun juga akan ditinggalkan. Bahkan dia akan melakukan cek rutin ke dokter tersebut untuk memastikan kesembuhannya. Hal ini ditambah dengan penyebab sakitnya yaitu karena terlalu sibuk bekerja hingga tidak ada waktu untuk istirahat. Kebiasaan ini sangat mengindikasikan bahwa pelaku dialog berasal dari kelas atas.

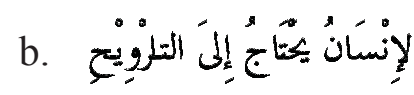

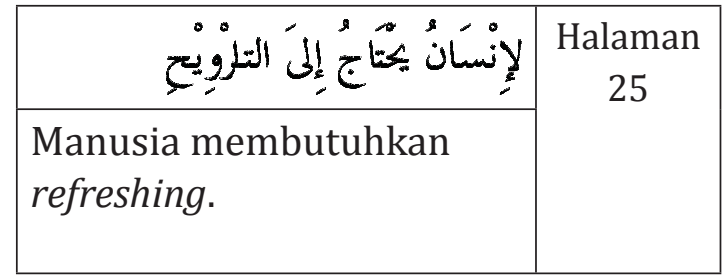

Bentuk sosialisasi habitus

kelas atas dalam buku Al-Arabiyah Bayna Yadaik jilid 2 juga banyak ditampilkan dengan menggunakan ilustrasi aktivitas-aktivitas kelas dominan atau kelas atas. Salah satu habitus kelas atas yang banyak digunakan dalam buku tersebut adalah الزَّْوِيْحِ 'refreshing'.

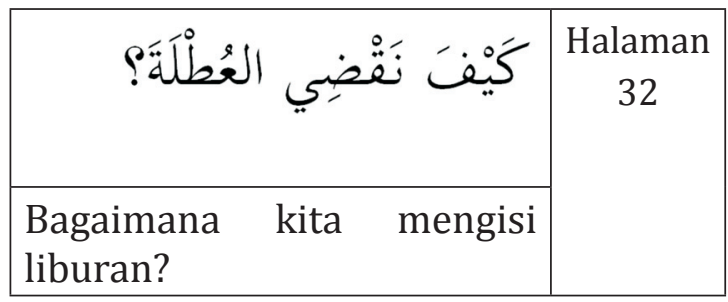

Aktivitas "refreshing" atau bertamasya ke tempat wisata pada waktu liburan merupakan sebuah aktivitas dan menjadi sebuah kebiasaan atau habitus kelas atas. Maksud ini bukan berarti bahwa kelas bawah tidak diperbolehkan berliburan atau refreshing melainkan maksudnya yaitu menjelaskan bahwa kelas ataslah yang lebih sering melakukan aktivitasini. Kebiasaan berliburanini dikategorikan dalam habitus kelas atas. Tempat wisata bermacammacam, seperti ke pantai, museum, dan berkemah, sedangkan waktu melakukan aktivitas ini yaitu pada saat liburan setelah merasakan penatnya bekerja atau belajar. 


\begin{tabular}{|c|c|}
\hline 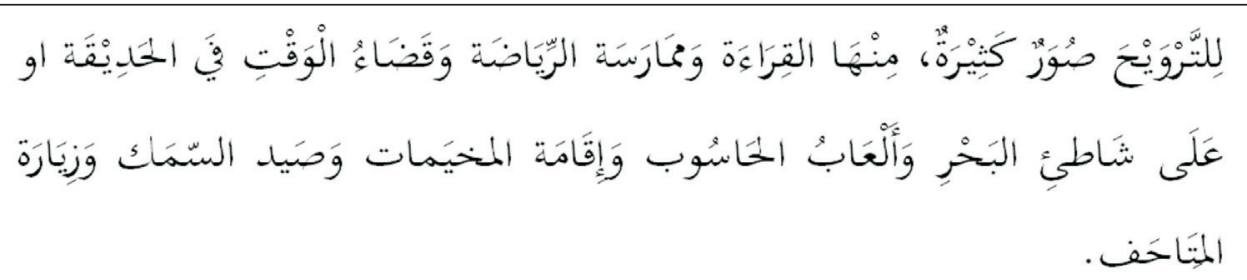 & $\begin{array}{c}\text { Halaman } \\
29\end{array}$ \\
\hline $\begin{array}{l}\text { Refreshing mempunyai bentuk yang banyak, seperti membaca, berolahraga, } \\
\text { menghabiskan waktu di kebun atau di pantai, bermain laptop, berkemah, } \\
\text { memancing ikan, dan mengunjungi museum-museum }\end{array}$ & \\
\hline
\end{tabular}

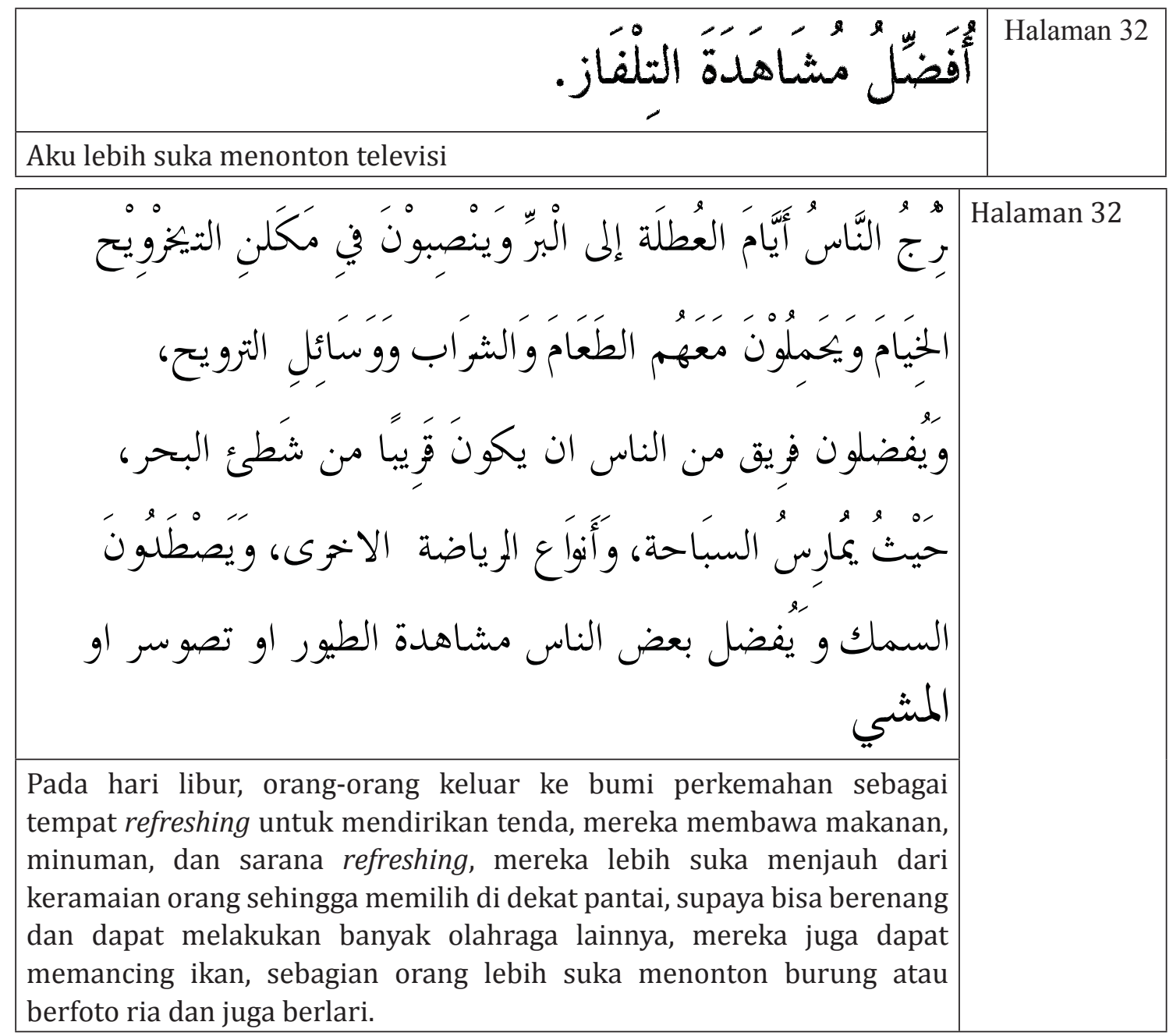

Banyak sekali bacaan yang menggunakan latar belakang aktivitas "refreshing" atau berlibur. Habitus ini merupakan habitus yang paling banyak menjadi sumber cerita. Selain menggunakan istilah-istilah tersebut, simbolisasi kelas atas juga tampak dalam pemilihan benda-benda yang digunakan untuk refreshing, seperti televisi, laptop, alat pancing, dan alat untuk mengambil gambar (kamera). Benda-benda tersebut mengindikasikan bahwa pelaku berasal dari kelas atas. 


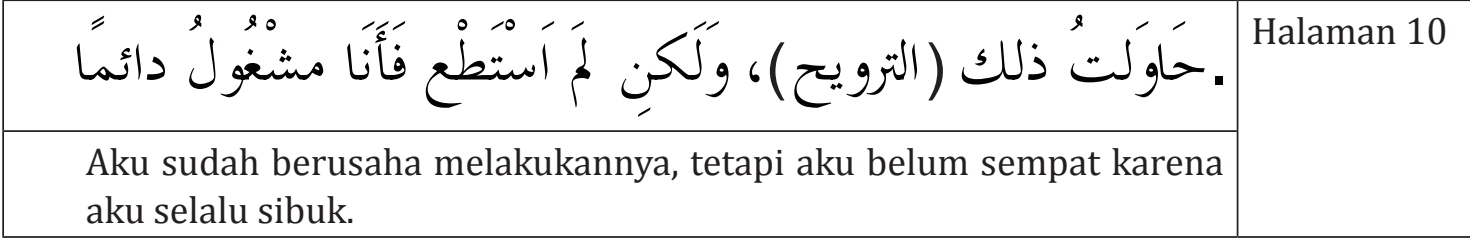

Habitus "refreshing" dalam buku Al-Arabiyah Bayna Yadaik jilid 2 juga digunakan dalam bacaan dialog mengenai kesehatan. Dialog tersebut berisi mengenai penyebab pelaku jatuh pingsan dan masuk rumah sakit, yaitu karena hidupnya dipenuhi dengan bekerja di perusahaan hingga tidak ada waktu untuk refreshing. Dialog ini sangat jelas mengindikasikan bahwa pelaku berasal dari kelas atas yang mempunyai pekerjaan yang terjamin di sebuah perusahaan. Dia mendapat posisi tinggi di perusahaannya hingga disibukkan dengan pekerjaannya tanpa mempunyai waktu untuk berlibur.
Simbolisasi Kelas Atas

\begin{tabular}{|c|c|}
\hline 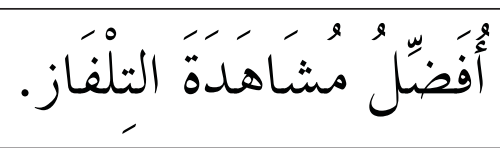 & $\begin{array}{c}\text { Halaman } \\
32\end{array}$ \\
\hline $\begin{array}{l}\text { Aku lebih suka menonton } \\
\text { televisi }\end{array}$ & \\
\hline
\end{tabular}

Habitus kelas atas banyak ditampakkan dalam simbolisasi. Simbolisasi ini cukup menunjukkan bahwa pelaku berasal dari kelas atas. Simbolisasi ini dapat berupa benda yang digunakan, seperti seorang anak yang memilih menonton televisi untuk mengisi waktu liburnya. Televisi ini cukup menjadi simbol bahwa dia berasal dari kelas atas karena belum tentu kelas bawah memiliki benda ini. Akan tetapi, hal ini tidak bermaksud bahwa kelas bawah tidak boleh memilikinya, hanya saja benda ini sudah tentu dimiliki oleh kelas atas.

\begin{tabular}{|c|c|}
\hline 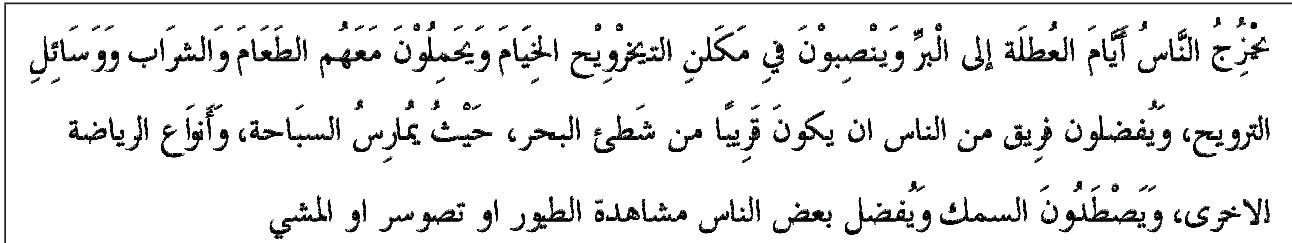 & $\begin{array}{c}\text { Halaman } \\
32\end{array}$ \\
\hline $\begin{array}{l}\text { Pada hari libur, orang-orang keluar ke bumi perkemahan sebagai tempat } \\
\text { refreshing untuk mendirikan tenda, mereka mebawa makanan, minuman, dan } \\
\text { sarana refreshing, mereka lebih suka menjauh dari keramaian orang sehingga } \\
\text { memilih di dekat pantai, supaya bisa berenang dan dapat melakukan banyak } \\
\text { olahraga lainnya, mereka juga dapat memancing ikan, sebagian orang lebih } \\
\text { suka menonton burung atau berfoto ria dan juga berlari. }\end{array}$ & \\
\hline
\end{tabular}


Simbolisasi benda ini juga ditemukan dalam bacaan yang sama pula bahwa seorang anak memilih bermain laptop untuk mengisi waktu melakukan refreshing. Benda ini merupakan simbol benda yang dimiliki oleh kelas atas, baik dari ekonomi maupun pendidikan. Laptop dan televisi bagi kelas atas banyak difungsikan sebagai alat hiburan untuk mengurangi kepenatan bekerja maupun belajar. Sebaliknya, bagi kelas bawah, benda ini merupakan barang mewah yang memerlukan uang banyak untuk mendapatkannya.

\section{Aktivitas Sehari-hari Kelas Atas}

Mekanisme sosialisasi habitus kelas dominan selanjutnya adalah sosialisasi mengenai berbagai aktivitas atau kegiatan sehari-hari yang biasa dilakukan keluarga atau anggota keluarga. Aktivitas sehari-hari sangat menunjukkan kebiasaan seorang pelaku. Dia berasal dari kelas atas atau bawah. Hasil penelitian menunjukkan bahwa sebagian besar aktivitas individu yang digambarkan dalam buku Al-Arabiyah Bayna Yadaik jilid 2 adalah aktivitas-aktivitas yang biasa dilakukan oleh kalangan atas.

\begin{tabular}{|c|c|}
\hline كَيْفَ سَنْقْى او لادنَا العطلةَّ & $\begin{array}{l}\text { Halaman } \\
\quad 32\end{array}$ \\
\hline $\begin{array}{l}\text { Bagaimana anak kita akan } \\
\text { mengisi liburan? }\end{array}$ & \\
\hline
\end{tabular}

Kebiasaan berlibur ketika libur sekolah ditemukan dalam buku ini. Ibu dan bapak mengumpulkan semua anaknya untuk berdiskusi mengenai kegiatan yang akan dilakukan. Kebiasaan liburan mengisyaratkan kebiasaan masyarakat kelas atas. Hal ini bukan berarti kelas bawah tidak boleh melakukannya, melainkan secara umum, kebiasaan ini sering dilakukan oleh kelas atas daripada kelas bawah. Kebiasaan ini digolongkan menjadi habitus kelas atas.

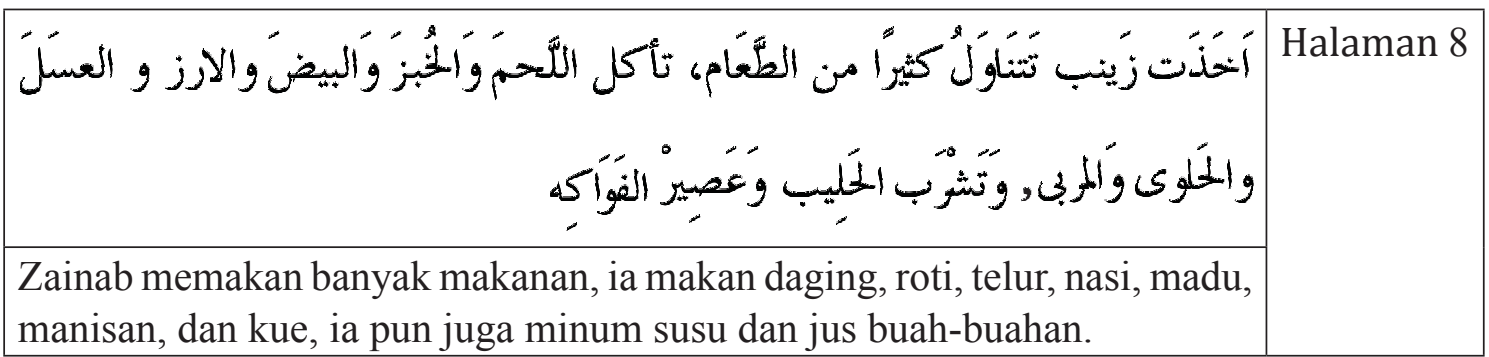

Selain liburan, kebiasaan kelas atas juga dapat dilihat dari pola makan. Bacaan lain menceritakan bahwa kebiasaan kelas atas adalah makan banyak hingga lupa banyaknya lemak yang tertimbun di dalam tubuh sehingga mengakibatkan banyak penyakit. Kebiasaan makan banyak sering dilakukan oleh kelas atas dari pada kelas bawah. Sebab, bagi kelas bawah, makanan adalah sesuatu yang sangat berharga sehingga perlu dihemat untuk besok lagi. 


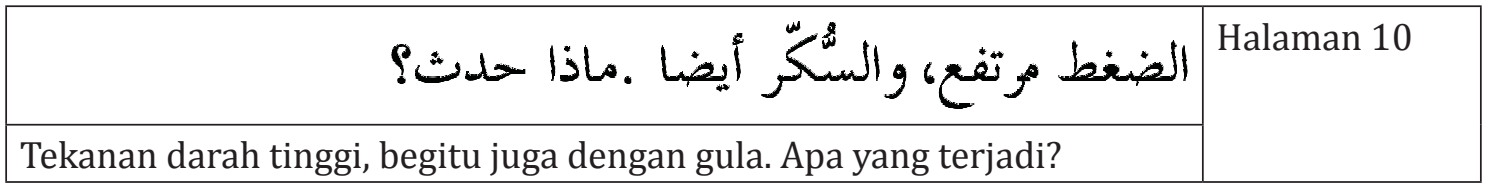

Habitus kelas atas juga dapat menunjukkan penyakit-penyakit yang muncul dalam kelas ini, yaitu penyakit darah tinggi, gula, dan kolesterol. Penyakit ini dapat menunjukkan habitus kelas atas karena penyakit ini disebabkan karena banyaknya lemak dalam tubuh dan lemak tersebut berasal dari makanan seperti daging, telor, roti, dan kacang. Makanan tersebut juga menunjukkan simbol habitus yang biasa dikonsumsi oleh kelas atas. Pnyakit tersebut dapat dikategorikan sebagai habitus kelas atas.

\section{Profil Kelas Atas}

\begin{tabular}{|c|c|}
\hline 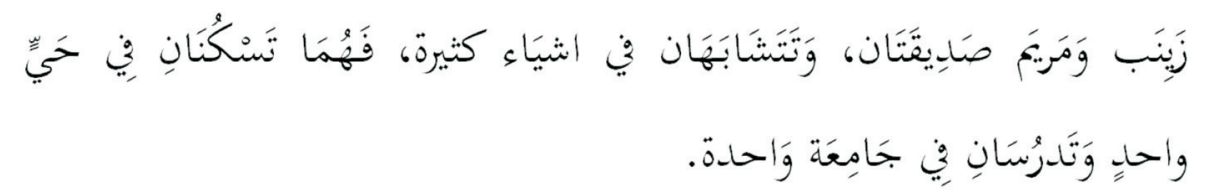 & Halaman 7 \\
\hline $\begin{array}{l}\text { Zainab dan Maryam adalah dua teman, mereka mempunyai kesamaan pada } \\
\text { banyak hal, mereka tinggal di satu wilayah dan kuliah di satu universitas. }\end{array}$ & \\
\hline
\end{tabular}

Habitus kelas atas sering digambarkan dengan suatu profil. Profil ini dapat menunjukkan dengan jelas habitus suatu kelas. Profil habitus kelas atas yang terdapat dalam buku Al-Arabiyah Bayna Yadaik jilid 2 yaitu profil pendidikan. Banyak ditemukan bacaan yang menunjukkan bahwa pelaku merupakan seorang mahasiswa yang sedang belajar di sebuah perguruan tinggi. Profil ini menunjukkan suatu habitus kelas atas. Maksud ini bukan berarti bahwa kelas bawah tidak boleh melanjutkan sekolah sampai perguruan tinggi, melainkan profil ini biasanya ditunjukkan oleh kelas atas. Menjadi seorang mahasiswa dapat dikategorikan sebagai habitus kelas atas.

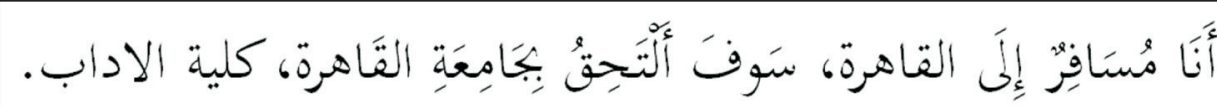

Halaman 154

Saya pergi ke Kairo, saya akan melanjutkan studi di universitas Kairo Fakultas Sastra.

Hal ini ditambah dengan sebuah bacaan yang menunjukkan bahwa seorang anak ingin melanjutkan sekolah tingginya di luar negeri. Hal ini sangat jelas menunjukkan bahwa pelaku berasal dari kelas atas karena sangat kecil kemungkinan kelas bawah dapat melakukan hal tersebut. 


\begin{tabular}{|c|c|}
\hline 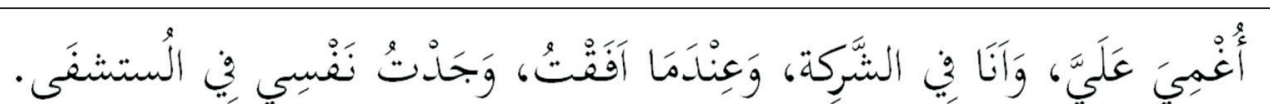 & $\begin{array}{l}\text { Halaman } \\
\quad 25\end{array}$ \\
\hline $\begin{array}{l}\text { Saya sehabis pingsan ketika saya di perusahaan, pada saat saya sadar aku } \\
\text { menyadari bahwa saya berada di rumah sakit. }\end{array}$ & \\
\hline
\end{tabular}

Selain profil pendidikan, habitus kelas atas dapat ditunjukkan dari pekerjaan yang dia bekerja. Berdasarkan penelitian terhadap buku Al-Arabiyah Bayna Yadaik jilid 2 ditemukan suatu bacaan yang menunjukkan seorang bapak yang bekerja di perusahaan. Profil ini cukup menunjukkan bahwa bapak tersebut berasal dari kelas atas karena dalam koteks ini bapak tersebut ditemukan jatuh pingsan di perusahaan tempat dia bekerja hingga dibawa ke rumah sakit. Hal itu dikarenakan terlalu disibukkan dengan pekerjaannya hingga tidak ada waktu untuk beristirahat.

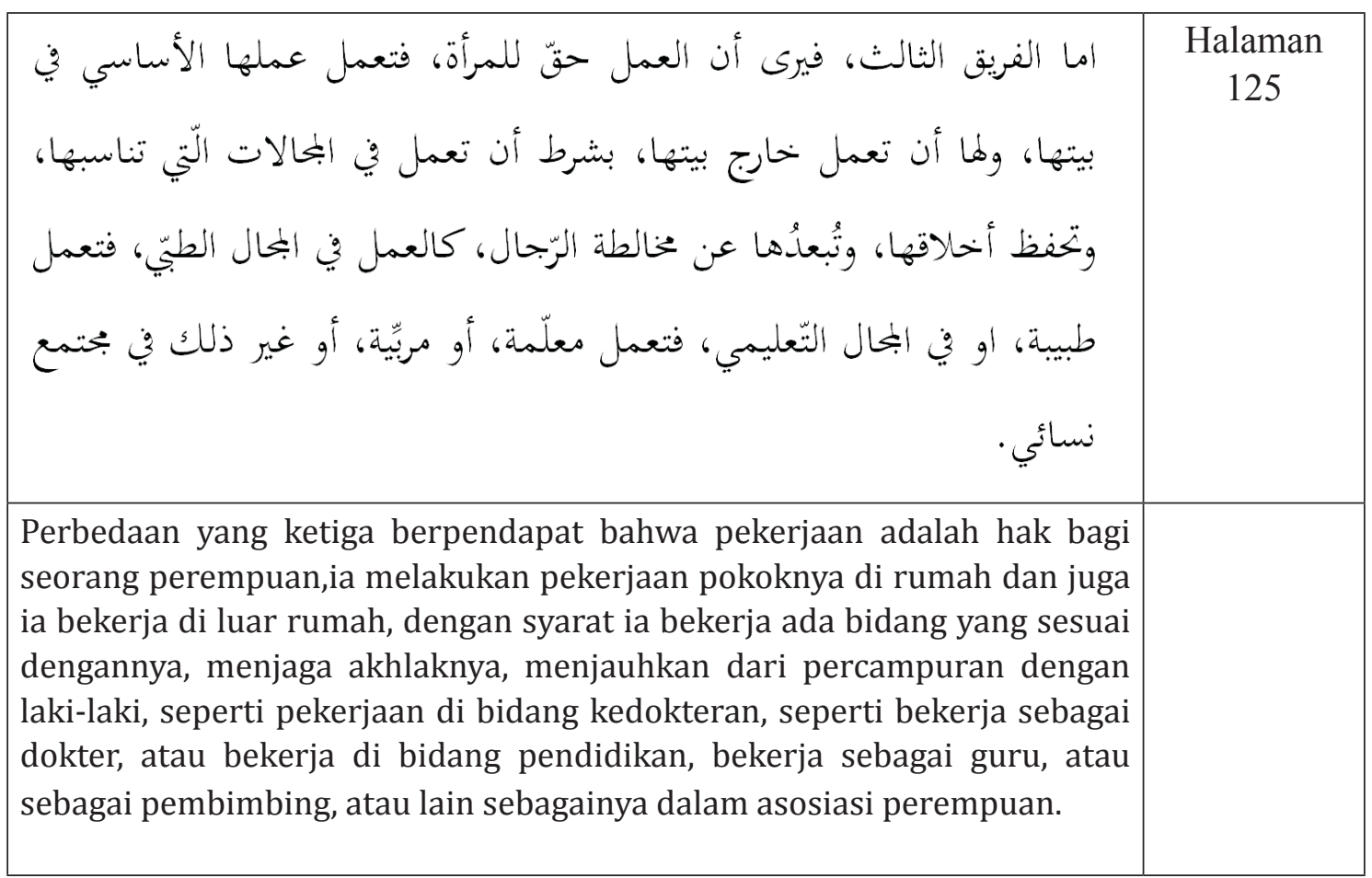

Profesi lain juga ditemukan dalam bacaan lain yaitu seorang guru dan perawat. Profesi ini menunjukkan habitus kelas atas karena hal ini tidak semua orang dapat bekerja dalam profesi tersebut karena memerlukan tingkat pendidikan yang memadai. Profesi tersebut dapat dikategorikan sebagai habitus kelas atas.

\section{Habitus Kelas Bawah}

Habitus kelas bawah juga ditemukan dalam buku Al-Arabiyah Bayna Yadaik jilid 2. Akan tetapi, jumlah jumlahnya lebih sedikit daripada habitus kelas atas. Sosialisasi mengenai habitus masyarakat kelas bawah dilakukan melalui beberapa pencitraan mengenai masyarakat terdominasi. 


\begin{tabular}{|c|c|}
\hline كان طلاب العلم - في الماضى - يسافرون من بلد إلى بلد, لطلب العلم, وكانوا & $\begin{array}{c}\text { Halaman } \\
103\end{array}$ \\
\hline $\begin{array}{l}\text { Pada zaman dahulu, para pelajar melakukan perjalanan dari satu negara ke } \\
\text { negara lain untuk menuntut ilmu dan dahulu mereka menghadapi banyak rasa } \\
\text { capek dalam perjalanannya, sehingga mereka mengendarai unta berhari-hari } \\
\text { dan berbulan-bulan. }\end{array}$ & \\
\hline
\end{tabular}

Mekanisme sosialisasi habitus kelas terdominasi dilakukan melalui penggambaran karakter atau profilnya. Profil tersebut dilihat dari segi pendidikan dan ekonominya. Habitus kelas bawah mempunyai profil pendidikan yang rendah. Bacaan dalam buku ini menceritakan mengenai pendidikan pada zaman dahulu yang sangat berbeda dengan zaman sekarang. Seorang murid harus menempuh perjalanan yang panjang tanpa adanya alat transportasi untuk menuntut ilmu. Seorang guru tidak mendapat upah sepeserpun dari pekerjaannya dan yang diharapkan hanya balasan dari Allah. Penceritaan ini menunjukkan suatu habitus kelas bawah karena hal ini sangat berbeda halnya dengan kelas atas yang semua fasilitas tersedia.

\begin{tabular}{|c|c|}
\hline سأغترب للعمل خارج وطني. & $\begin{array}{c}\text { Halaman } \\
128\end{array}$ \\
\hline $\begin{array}{l}\text { Saya akan merantau ke luar } \\
\text { negeri untuk bekerja. }\end{array}$ & \\
\hline المال كثيرة هنالك، والحياة سهلة. & \\
\hline $\begin{array}{l}\text { Di sana uang ada banyak dan } \\
\text { kehidupanpun mudah. }\end{array}$ & \\
\hline
\end{tabular}

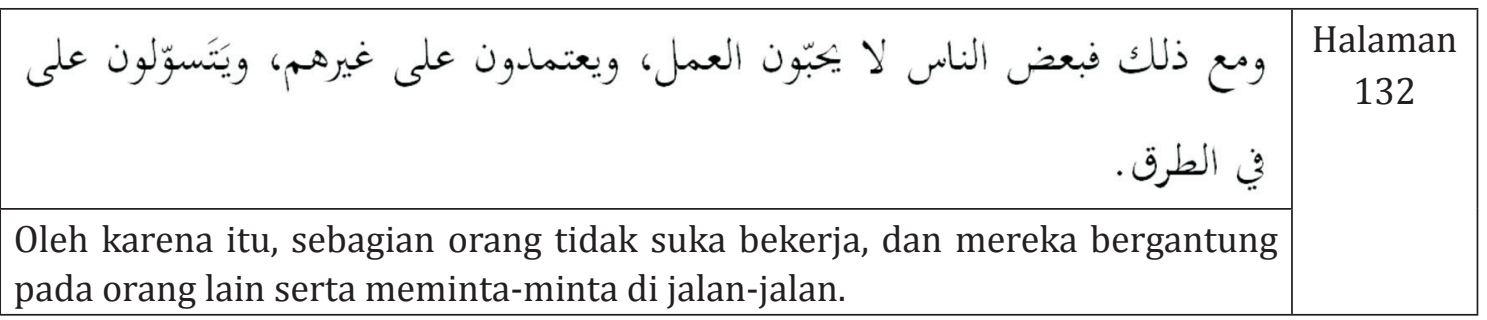
وقاد يكون من الأسباب (جربمة) انتشار الفقر والجوع في المحتمع.

Dan terkadang penyebab kriminalitas yaitu meluasnya kemiskinan dan kelaparan dalam masyarakat.

Penggambaran habitus kelas bawah ini juga ditunjukkan melalui profesi. Profesi kelas bawah ini tidak menentu dan bahkan banyak yang menjadi pengangguran dan harus merantau ke kota atau tempat lain agar mendapatkan pekerjaan dan hidup yang layak. Bahkan, hal yang lebih parah yang dihasilkan banyaknya pengangguran adalah banyak kriminalitas yang terjadi di suatu daerah. Kriminalitas 
tersebut seperti pencurian, perampokan, pembunuhan. Hal ini dapat diperkirakan bahwa asal masalahnya adalah ekonomi yang kurang mendukung. Akibatnya, pelaku menghalalkan segala cara untuk mendapatkan uang dan menyambung hidup. Karakter ini tidak akan ditemui dalam habitus kelas atas sehingga hal ini dikategorikan dalam habitus kelas bawah.

\section{SIMPULAN}

Hasil penelitian menunjukkan bahwa sebagian besar kalimat yang terdapat dalam buku Al-Arabiyah Bayna Yadaik jilid 2 memuat habitus kelas dominan (kelas atas). Ada beberapa mekanisme yang digunakan untuk menyosialisasikan habitus kelas atas melalui buku tersebut. Mekanisme tersebut adalah, pertama, menceritakan kebiasaan-kebiasaan kelasatas misalnya refreshing, berobat ke dokter, bermain laptop, menonton televisi, serta banyak makan. Kedua adalah memperlihatkan atau menceritakan benda-benda yang biasa dimiliki kelas atas, misalnya televisi, laptop, alat pancing, peralatan kemah, dan kamera. Ketiga adalah menggambarkan profil atau ciri-ciri kelas atas, misalnya melanjutkan sekolah hingga ke perguruan tinggi dan bekerja di perusahaan. Habitus-habitus tersebut sangat mengindikasikan sebagai habitus kelas atas.

Habitus kelas bawah yang digambarkan dalam buku Al-Arabiyah Bayna Yadaik jilid 2 jumlahnya lebih sedikit daripada kelas atas. Habitus kelas bawah diceritakan melalui mekanisme dengan menggambarkan karakter kelas bawah, misalnya pendidikan rendah dan banyak yang menganggur hingga banyak terjadinya kriminalitas.

\section{DAFTAR PUSTAKA}

Martono, N. (2012). Kekerasan simbolik di sekolah. Jakarta: Raja Grafindo Persada.

Munawwir, A.W. (1997). Al-Munawwir kamus Arab-Indonesia. Surabaya: Pustaka Progressif.

Sudaryanto. (2015). Metode dan aneka teknik analisis bahasa. Yogyakarta: Sanata Dharma University Press.

Susilo, E. (2012). Orkes Simfoni Jakarta dalam Perspektif Habitus Bourdieu. Journal of Urban Society's Art. Volume 12 Number 2, October 2012. Pascasarjana Universitas Gadjah Mada Jogjakarta.

Wahyuni, L. (2008). "Kekuasaan Simbolik dalam Wacana Politik di Media Cetak". Jurnal Kajian Linguistik dan Sastra. Vol. 20, No. 2, Desember 2008. IKIP Budi Utomo Malang.
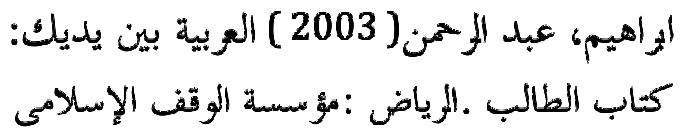